https://doi.org/10.25143/socr.14.2019.2.035-046

\title{
Konstitucionālās tiesības uz streiku: ǵimenes ārstu streika gadījums
}

\author{
Kitija Bite \\ Rìgas Stradiṇa universitāte, Juridiskā fakultāte, Latvija \\ kitija.bite@rsu.lv
}

\section{Kopsavilkums}

Starptautiskajās tiesību normās ir iekḷautas cilvēka brīvības un tiesības. Tās ietver vārda brīiibu, tiesības uz darbu, tiesības apvienoties un tiesības uz streiku, ja darba tiesisko attiecību laikā pusēm rodas strīdi, u. c. tiesības. Latvijas Republikas Satversmes (turpmāk - Satversme) 108. pantā paredzētas strādājošo tiesības uz streiku kā galējo līdzekli darba strīdu risināšanai. Sistēmiski šì konstitūcijas norma tiek regulēta ar Darba strīdu likumu un Streiku likumu. Varētu šḳist, ka Latvijā katram strādājošajam ir nodrošinātas tiesības streikot, kā tas paredzēts Satversmē. Tomēr ǵimenes ārstu streiks 2017. gadā parādīja, ka streiku îstenošanā ir problēmas.

Pirmkārt, tiesības streikot pašlaik ir attiecināmas tikai uz vienu nodarbinātības veidu - darba tiesiskajām attiecībām. Taču tikai dạıai ğimenes ārstu nodarbinātības attiecības balstìtas uz darba līguma pamata, tādējādi piemērot valstī spēkā esošo streiku regulējumu savu kolektīvo interešu aizsardzībai var tikai dalı gimenes ārstu.

Otrkārt, Darba strīdu likums streiku kā galējo līdzekli l̦auj piemērot tikai kolektīvo interešu aizsardzībai (koplīguma noslēgšanas ietvaros), bet ne publisko tiesību līguma ietvaros.

G̦imenes ārstu streiks parādīja, ka Latvijā tikai daḷēji izpildītas starptautiskās normas, jo tiesības streikot ir paredzētas, bet šì norma attiecināma tikai uz tām personām, kuras nodarbinātas uz darba līguma pamata un tikai koplīguma domstarpību gadïjumos. Lai risinātu situāciju un turpmāk nodrošinātu katras nodarbinātās personas tiesības streikot, nepieciešams grozìt Darba strīdu likumu, paplašinot darba strīdu subjektu loku.

Atslēgvārdi: darba strīds, streiks, nodarbinātība, strādājošais, ğimenes ārstu streiks, darba līgums, koplīgums. 
Kitija Bite. Konstitucionālās tiesības uz streiku: gimenes ārstu streika gadijums

\section{levads}

Valsts konstitūcija aizsargā cilvēka pamattiesības un brīvības, apliecinot, ka Latvijā tiek atzītas demokrātiskas sabiedrības vērtības. Viena no šādām starptautiski atzītām vērtībām ir strādājošo tiesības uz streiku. Tomēr strādājošo tiesības streikot nav absolūtas, tās var ierobežot Satversmē noteiktajā kārtībā ar likumu.

Izvērtējot Lat vijā noteiktās tiesības uz streiku, var secināt, ka Satversmē gan paredzētas visu strādājošo tiesības uz streiku, taču Streiku likums tās ierobežo noteiktām nodarbināto grupām, kas nodarbinātas valsts dienestā un sabiedrības neatliekamo vajadzību nodrošināšanā. G̣imenes ārsti nepieder nodarbināto grupām, uz kurām attiecas streikošanas aizliegums. Tādējādi gimenes ārstiem likumdevējs ir pieškīiris tiesības uz streiku.

Tajā pašā laikā speciālajos likumos - Streiku likumā un Darba strīdu likumā -, kuri ir vienīgie, kas regulē strādājošo tiesības uz streiku, paredzētas tiesības streikot tikai tiem strādājošajiem, kuri ir nodarbināti uz darba līguma pamata. G̦imenes ārsti Latvijā var tikt nodarbināti divos veidos, t. i., kā pašnodarbinātas personas un kā darbinieki ārstniecības iestādē, tādēl tiesības streikot ir tikai tiem gimenes ārstiem, kuri ir nodarbināti uz darba līguma pamata. No minētā var secināt, ka vienlīdzīgā situācijā esošām personām rodas dažādas tiesiskās sekas. Šāda situācija nav objektīvi attaisnojama. Valsts ir radījusi tiesisko regulējumu, kas piel̦auj atšķirīgu attieksmi konstitucionālo tiesību īstenošanā.

Turklāt Darba strīdu likumā tiesības streikot ir piešḳirtas vien tajos gadījumos, kad notiek sarunas par koplīguma vai tā grozījumu noslēgšanu (kolektīvo interešu aizsardzību). Būtu jāpārvērtē, kāpēc strādājošiem nav tiesību uz streiku citos gadījumos.

G̦imenes ārstu streiks 2017. gadā skaidri parādijja problēmas, kuras Latvijā pastāv kopš Darba strīdu likuma spēkā stāšanās brīža 2003. gada 1. janvārī, bet iepriekš nebija aktuālas, jo streika institūts valstī nav attīstìts. Ar pašreizējo tiesisko regulējumu Latvija formāli ir izpildījusi starptautiskās prasības nodrošināt strādājošajiem tiesības uz streiku, nosakot tās konstitūcijā, bet realitātē tiesības uz streiku ir tikai daḷai strādājošo un tikai par koplīguma noslēgšanas jautājumiem.

Šìs publikācijas mērḳis ir izvērtēt strādājošo konstitucionālo tiesību uz streiku tiesisko regulējumu un tā piemērošanu, konstatēt problemātiku gan giimenes ārstiem, gan citiem nodarbinātajiem, kuri nav darba tiesiskās attiecības, īstenot tiesības uz streiku, kā arī ieteikt problēmu risinājumu.

Publikācijas sagatavošanā izmantotais materiāls un metodes - normatīvo aktu, tiesu prakses un zinātniskās literatūras analizze un apraksts, indukcijas un dedukcijas, dogmatiskā, log̣iski konstruktīvā, kā arī grafiskā metode. Darbā izmantotas tiesību normu interpretācijas metodes: gramatiskā, sistēmiskā un teleologiskā metode.

Šajā rakstā turpinu jau agrāk iesākto pētījumu par ǵimenes ārstu tiesībām uz streiku, kas uzrakstīts angḷu valodā un iesniegts Rīgas Stradiṇa universitātes konferenču rakstu krājumam $7^{\text {th }}$ International Interdisciplinary Scientific Conference "Society. Health. Welfare". 
Kitija Bite. Konstitucionālās tiesības uz streiku: gimenes ārstu streika gadijums

\title{
Strādājošo tiesības uz streiku kā biedrošanās brīvības forma
}

\begin{abstract}
“Dabiskā cilvēka privilēgija ir ne tikai darboties savā labā, bet arī spēt saskaṇot savu rīcību un apvienot pūles ar saviem līdzcilvēkiem, darbojoties kopīgi kāda mērḳa sasniegšanai. Biedrošanās brīvības svarīgums izpaužas apstāklī, ka domu, uzskatu un vārda brīvībai būtu l,oti ierobežota nozīme, ja netiktu nodrošināta iespēja savas domas, idejas, ticību un uzskatus paust līdzcilvēkiem, kuri ir apvienojušies līdzīgu mērḳu labad." [20, 4]
\end{abstract}

Tiesības paust savu viedokli un aizstāvēt likumīgās intereses demokrātiskā sabiedrībā tiek attiecinātas uz cilvēktiesībām, proti, uz pilsoniskajām un politiskajām tiesībām. Latvijā šĩs tiesības ir ietvertas vairākās konstitūcijas normās: tiesībās uz vārda brīvību, kas ietver tiesības brīvi iegūt, paturēt un izplatīt informāciju, paust savus uzskatus $[8$, 100. pants]; tiesībās apvienoties biedrībās, politiskās partijās un citās sabiedriskās organizācijās $[8,102$. pants]; valsts aizsargā iepriekš pieteiktu miermīlīgu sapulču un gājienu, kā arī piketu brīvību $[8,103$. pants] un strādājošajiem ir tiesības uz koplīgumu, kā arī tiesības streikot $[8,108$. pants]. Tomēr neviena no šīm tiesībām nav absolūta - tās visas var ierobežot likumā paredzētajos gadījumos, lai aizsargātu citu cilvēku tiesības, demokrātisko valsts iekārtu, sabiedrības drošību, labklājību un tikumību $[8,116$. pants].

Konstitūcijā ietvertās tiesības uz viedokḷa paušanu nosacīti var iedalīt individuālajās tiesībās (informācijas iegūšana un uzskatu paušana) un kolektīvajās tiesībās (tiesības apvienoties, tiesības organizēti paust savu viedokli sapulcēs, gājienos un piketos, tiesības streikot). Tāpat ir jānodala tiesības, kas saistītas ar viedokḷa paušanu nodarbinātības jomā un ārpus tās. Konstitūcijā šīs tiesības sistēmiski izkārtotas šādi: 100. pants kā tiesības uz vārda brīvību tās visplašākajā izpausmē; 102. pants kā tiesības uz apvienošanos un biedrošanos; 103. pants - tiesības uz viedokḷa publisku paušanu. Atsevišḳi nodalītas ir strādājošo tiesības uz publisku viedokḷa paušanu - tiesības streikot.

Valsts aizsargā strādājošo tiesības uz streiku, kas juridiskā izpausmē ir gan pulcēšanās brīvības, gan nodarbinātības tiesību īstenošanas tvērumā ietilpstoša darbība. Streiks ir kolektīvā interešu strīda risināšanas veids, kas izpaužas tādējādi, ka uzṇēmuma, nozares darbinieki vai darbinieku grupa brīvprātīgi pilnībā vai dạēji pārtrauc darbu ar nolūku panākt prasību izpildi [12, 1. panta trešais punkts]. Var secināt, ka streikam nepieciešamie kritēriji ir kolektīvs interešu strīds, brīvprātība, pilnīga vai daḷēja darba pārtraukšana, turklāt pastāv arī kādas prasības, kuru izpildi streikotāji nodomājuši panākt.

Konstitūcijā noteiktās cilvēktiesības tiek regulētas ar atseviškịiem likumiem par pulcēšanās un biedrošanās brīvību, un tās tiek regulētas ar speciāliem normatīvajiem aktiem. Viens no tiem ir likums "Par sapulcēm, gājieniem un piketiem" [10], kas ir primārais normatīvais akts, ar kuru valsts garantē un aizsargā miermīlīgas pulcēšanās brīvību. Pulcēšanās brīvība var izpausties kā sapulce, gājiens vai pikets. Citas valsts atzītas pulcēšanās formas ir publiski izklaides, svētku, sporta un citi pasākumi, kuriem noteikts speciāls regulējums [11]. Šìs normas attiecināmas uz pulcēšanās brīvību. 
Biedrošanās brīvība Latvijā tiek īstenota valsts noteiktās formās, kas ir šādas: politiskās partijas, arodbiedrības, religiskās organizācijas, biedrības un nodibinājumi. Katru no šiem biedrošanās brīvības veidiem regulē atsevišķa tiesību norma.

Likumā "Par sapulcēm, gājieniem un piketiem" noteikts, ka sabiedrībai ḷauts izteikt viedokli par dažādiem sabiedriski nozīmīgiem politiska, ekonomiska un sociāla rakstura jautājumiem, savukārt Streiku likumā paredzētas strādājošo aktīvas darbības, t. i., streika tiesības, kas saistītas ar kolektīvo interešu aizsardzību.

Likuma "Par sapulcēm, gājieniem un piketiem" normas l̦auj secināt, ka sapulces, gājieni un mītiṇi ir pulcēšanās brīvības izpausme, kas saistìta ar vārda brīiību un kas paredz sabiedrības tiesības paust savu nostāju par politiskiem, ekonomiskiem un sociāliem jautājumiem.

Savukārt Streiku likums regulē nodarbināto tiesības pārtraukt darbu, lai panāktu sev vēlamu rezultātu tām prasībām, kuras iesniegtas darba devējam koplīguma noslēgšanas sarunu laikā. Latvijā ir nodalītas šīs divas biedrošanās un pulcēšanās formas, jo katrai no tām ir savi mērḳi, ierobežojumi un izpildāmās prasības, lai valsts aizsargātu konstitūcijā garantētās pulcēšanās un biedrošanās brīvības.

Satversmes tiesa ir spriedusi, ka tiesïbas streikot tiek atzitas par vienu no personas pamattiesībām un demokrātiskas sabiedrības vērtībām. Tiesības streikot ir strādājošo konstitucionālās tiesības, un valstij ir pienākums nodrošināt šo tiesību îstenošanu [16, 7.1. punkts].

Arī starptautiskajās tiesību normās ir paredzētas tiesības uz streiku. Starptautiskajā paktā par ekonomiskajām, sociālajām un kultūras tiesībām noteikts, ka dalībvalstis apṇemas sekmēt tiesības streikot, ja tās tiek realizētas saskaṇā ar katras valsts likumiem $[6,8$. panta d punkts]. Eiropas Sociālajā hartā noteikts, ka valstis atzīst strādājošo un darba devēju tiesības uz kolektīvo rīcību interešu konfliktu gadījumos, ieskaitot tiesības uz streiku, ievērojot saistības, kas var rasties saskaṇā ar pirms tam noslēgtajiem kolektīvajiem lïgumiem $[5,6$. panta ceturtais punkts].

Šìs normas nepārprotami nosaka nacionālās valsts pienākumu ar saviem tiesību aktiem noteikt strādājošo tiesības uz kolektīvu rīcību, proti, streiku.

Kopš 1998. gada, kad spēkā stājās Streiku likums, Latvijā ir streikojuši atseviškłu nozaru darbinieki - pedagogi (1999), medicīnas darbinieki (2002), brīdinājuma streiks notika dzelzcelı nozarē (2001) un bija arī gimenes ārstu streiks (2017). [17]

Streikošanas tradīcijas Latvijā nav izkoptas un attīstītas kā citās valstīs [21], tādēl arī diezgan reti tiek piemērots atbilstīgs tiesiskais regulējumsun nav atklātas problēmas, kas saistās ar tiesiskā regulējuma interpretāciju un piemērošanu praksē. Tomēr Latvijas ǵimenes ārstu 2017. gadā pieteiktais streiks skaidri iezīmēja juridiskās problēmas, par kurām vairāk - raksta turpmākajā dạ̣ā. 
Kitija Bite. Konstitucionālās tiesības uz streiku: gimenes ārstu streika gadijums

\section{Streika tiesiskais regulējums}

Darba likumā paredzēta strīdu risināšana darba tiesiskajās attiecībās $[3,8$. nodaḷa "Strīdu izškiršana"], bet šis regulējums attiecas uz individuāli noslēgtiem darba līgumiem un neparedz tiesības streikot. Tas ir tiesiski korekti, jo saskaṇā ar starptautiskajām normām streiks ir kolektīvo strīdu risināšanas veids.

Tādējādi likumdevējs streika regulējumu ir iekḷāvis speciālajās tiesību normās. Darba strīdu likumā ir ietverta norāde par streiku kā galējo strīda izškirš̌anas līdzekli [4, 21. panta pirmā daḷa]. Bet Streiku likumā streiks paredzēts kā brīvprātīgas formas protests, lai personas panāktu savu prasību izpildi, pārtraucot vai daḷēji pārtraucot darbu $[12,1$. panta trešais punkts].

Sistēmiski kopumā šajās normās sniegta streika jēdziena saturiskā izpratne - strādājošie var pārtraukt darbu un streikot, lai panāktu savu prasību izpildi, ja neviens cits darba strīdu risināšanas veids nav devis rezultātu.

Arodbiedrību likumā ir stingri ierobežots subjektu loks, kas var pieteikt streiku. To var darìt tikai arodbiedrības. Arodbiedrībām valsts ir piešķīrusi ekskluzīvas tiesības: pārstāvot un aizstāvot strādājošo darba, ekonomiskās, sociālās un profesionālās intereses, arodbiedrībām ir tiesības veikt kolektīvas pārrunas, saṇemt informāciju un konsultēties ar darba devējiem, darba devēju organizācijām un to apvienībām, slēgt darba koplīgumus (generālvienošanās), pieteikt streikus, kā arī îstenot citas normatĩvajos aktos noteiktās tiesības [1, 12. panta pirmā dala].

Atbilstīgi šai normai arodbiedrības pārstāv savu biedru darba, ekonomiskās, sociālās un profesionālās intereses, tām ir tiesības iniciēt koplīguma sarunas un veikt pārrunas ar darba devējiem, kā arī slēgt koplīgumu. Ja koplīguma sarunās puses nesasniedz rezultātu, kā galējo domstarpību risināšanas līdzekli valsts ir noteikusi tiesības pieteikt streiku. Arodbiedrību likums ir sistēmiski saistìts ar Satversmes 108. pantu, kurā noteikts, ka strādājošajiem ir tiesības uz koplīgumu un streiku.

\footnotetext{
"Streika pieteikšanas procesu regulē Darba strīdu likums un Streiku likums. Streiku likuma mērḳis ir samērot darbinieku tiesību izmantot streiku kā līdzekli, lai panāktu savu interešu ievērošanu un izpildi ar darba devēja interesēm. Darbinieki ir ekonomiski atkarīgi no darba devēja un to starpā pastāv objektīva nevienlīdzība, proti, darbinieks ir vājākā puse attiecībās ar darba devēju. Līdz ar to tiesības uz streiku ir būtiska darbinieku un to pārstāvju tiesība, lai izlīdzinātu spēku nevienlīdzību un veicinātu darbinieku tiesību un pamatoto interešu ievērošanu. Streiks pats par sevi nav pamatinstruments, lai panāktu darbinieku interešu ievērošanu sarunās ar darba devējiem. Tas ir līdzeklis, lai piespiestu darba devēju sēsties pie saruna galda tad, kad darbinieku pūles panākt kompromisu neved pie rezultāta." [18, 77]
}

Darba strīdu likumā visi darba strīdi ir sadalīti divās lielās grupās - individuālos tiesību un kolektīvos strīdos, savukārt kolektīvie strīdi tiek dalīti tiesību un interešu strīdos. Streiks ir atļauts tikai kolektīvo interešu strīdu gadījumā (sk. 1. att.). 
Kitija Bite. Konstitucionālās tiesības uz streiku: gimenes ārstu streika gadijums

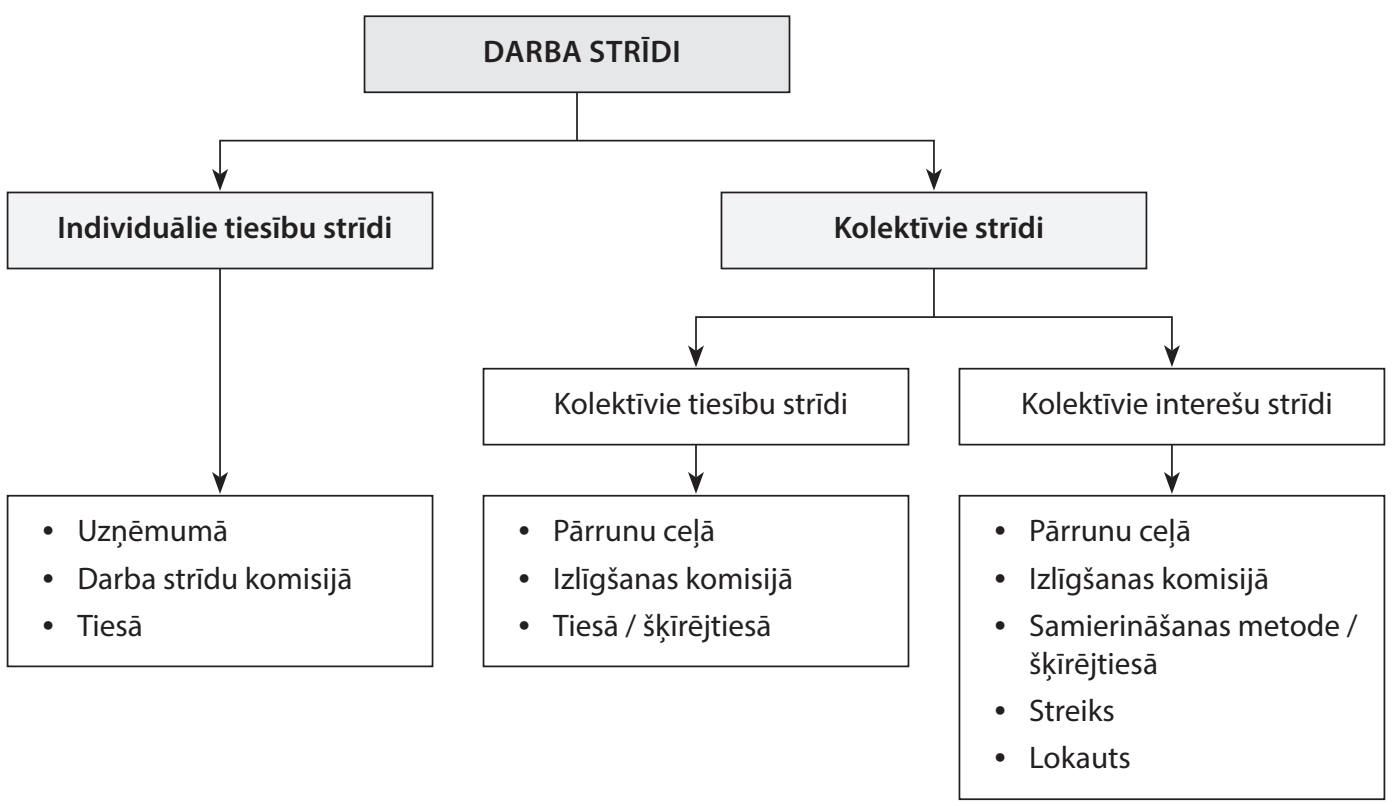

1. attēls. Darba strīdu veidu vizualizācija

Lai varētu izprast, kam ir tiesības uz streiku, l̦oti svarīgi ir atbildēt uz jautājumu, kas ir subjekti darba strīdos. Darba strīdu likumā ir nosaukti šādi subjekti: darbinieks, darba devējs vai abu pušu pārstāvji. Darbinieku pārstāv pilnvaroti (arodbiedrības) vai vienkārši (darbinieku sapulcē ievēlēti) pārstāvji, bet darba devējus var pārstāvēt darba devēju organizācija vai darba devēju organizāciju apvienības. Likumā paredzēts vēl viens darba strīdu subjekts - nozares pārstāvji [4, 2. panta pirmā daḷ a]. Piemēram, medicīnas darbiniekus pārstāv Veselības ministrija, bet pedagogus - Izglītības un zinātnes ministrija. Tikai Darba strīdu likuma 2. pantā noteiktie subjekti ir tiesīgi izmantot šajā likumā reglamentētās tiesības, un tiem jāpilda šeit noteiktie pienākumi.

Atbilstīgi Darba strīdu likumam darba strīdi ir iespējami tikai darba tiesisko attiecību ietvaros [4, 2. pants], savukārt darba tiesiskās attiecības veido tikai darba līgums kā saistības veids $[3,28$. pants].

Tādējādi iezīmējas pirmā juridiskā problēma - Latvijā nav noregulēta tādu darba strīdu izšḳiršana, arī ar streika palīdzību, ja starp pusēm nav noslēgts darba līgums. Šis nosacījums ir pretrunā ar konstitūcijā garantētajām cilvēktiesībām, t. i., ikvienam strādājošajam ir tiesības streikot. Nav juridiska pamata šīs cilvēktiesības ierobežot un ar likumu noteikt, ka streikot var tikai tie strādājošie, kuri noslēguši darba līgumu.

Darba strīdu likuma 21. panta pirmajā dạ̦ā un Streiku likuma pirmajā dạ̦ā noteikts, ka streiks ir kolektīvs interešu strīds. Tādēḷ jāanalizē, kas ir kolektīvas intereses, par kurām pušu starpā var rasties strīds. Darba strīdu likuma 13. pantā ir noteikti subjekti, kuri var tikt iesaistīti kolektīvā strīdā. Tie ir darbinieki vai darbinieku grupa, vai to 
pārstāvji, bet otru pusi pārstāv darba devējs, darba devēju grupa (2-4 darba devēji), darba devēju organizācijas, to apvienības vai nozares pārvaldes institūcija. Strīda priekšmets ir kolektīvo pārrunu process, kura laikā nosaka jaunus darba apstākḷus vai nodarbinātības noteikumus. No šìm divām normām var secināt, ka kolektīvs interešu strīds ir likumā noteikto pušu domstarpības par darba koplīguma noslēgšanas procesu. Tas saistïts ar jautājumiem, kurus puses apspriež koplīguma sarunās.

Tiesības uz streiku jāsaista ar koplīgumu - tas norādìts arī Satversmes 108. pantā, proti, strādājošajiem ir tiesības "uz koplīgumu, kā arī tiesības streikot". Likumdevējs nav šīs divas tiesības izteicis atsevišḳos teikumos vai atsevišḳos pantos, tāpēc šīs normas ir jātulko kopsakarībā. Arī Darba strīdu likuma 9. pantā, kurā definēts kolektīvo tiesību strīdu priekšmets, norādìts uz domstarpībām, kuras rodas, slēdzot, grozot, izbeidzot vai pildot darba koplīgumu. Tas norāda, ka kolektīvs tiesību strīds ir par spēkā esoša koplīguma izpildi, interpretāciju un piemērošanu, bet kolektīvs interešu strīds - par pušu pārrunām, kas saistītas ar koplīguma noslēgšanu.

Apkopojot šeit minēto, var secināt, ka kolektīvās intereses tiek ietvertas tajos jautājumos, kurus darbinieku pārstāvji vēlas iekḷaut koplīguma nosacỉjumos (neatkarīgi no tā, vai sarunas noris par jau spēkā esoša koplīguma grozī̌anu vai par jauna koplīguma izstrādi), kas uzlabo darbinieku stāvokli papildus Darba likumā vai individuālos darba līgumos noteiktajam. Nav saprotams, kāpēc streiks kā darba strīdu risināšanas veids būtu piemērojams tikai koplīguma slēgšanas vai grozišanas (kolektīvo interešu aizsardzības) gadijjumos, bet nav piemērojams par jau noslēgtu koplīgumu. Ja darba devējs, piemēram, nepilda koplīguma nosacījumus un izvairās no sarunām par to izpildi, to var vērtēt kā koplīguma vienpusēju laušanu, kas skar kolektīvās intereses. Būtu jāizsver iespēja pieškirt tiesības uz streiku kolektīvo tiesību aizsardzībai arī noslēgta koplīguma gadījumā.

Tātad tiesības streikot Latvijā tiesiski noregulētas ir tikai koplīguma noslēgšanas sarunu domstarpību risināšanai, kas izriet no darba tiesiskajām attiecībām. Citiem vārdiem sakot, kolektīvs interešu strīds var rasties tikai tajos uzn,ēmumos, kuros koplīgumu slēdz vai jau ir noslēguši nodarbinātie, kuru juridiskā saistība ar darba devēju ir darba līgums.

\section{Tiesības uz streiku: ǵgimenes ārstu streika analīze}

Ģimenes ārsti 2017. gadā pieteica streiku. Iepriekš vinịi vairāku gadu garumā ar Veselības ministriju risināja sarunas par finansējuma palielināšanu gimenes ārstu darbïbas nodrošināšanai, lai gimenes ārsti varētu īstenot valsts garantēto pacientu veselības aprūpes pieejamību $[19,12]$.

Sarunas ar Veselïbas ministriju vadijja Latvijas G̦imenes ārstu asociācija (turpmāk asociācija), kas pēc sava juridiskā statusa ir biedrība [2]. Lai gan asociācija ir profesionāla biedrība, kas pārstāv ǵimenes ārstus, šo biedrošanās formu nevar uzskatīt par arodbiedrību, kas ir tiesīga risināt sarunas par kolektīvajām interesēm un slēgt koplīgumu. Latvijā tiek juridiski nodalīti biedrošanās veidi - biedrības un nodibinājumi, arodbiedrības, 
religisiskās organizācijas un politiskās partijas. Katru no šīm biedrošanās formām regulē atsevišḳs likums, un Uzṇēmumu registrā tās tiek reg̣istrētas atsevišḳos reǵistros. Tādējādi asociācijai nav juridisku tiesību pieteikt ğimenes ārstu streiku, lai gan asociācijas darbība atgādina arodbiedrībai noteiktās un likumā aț̣autās aktivitātes.

2017. gada 26. maijā asociācijas biedru sapulcē tika pieñemts lēmums pieteikt ğimenes ārstu streiku, jo sarunas ar Veselïbas ministriju un valdỉbu nebija devušas rezultātu un nebija indikāciju, ka nākotnē tiks risināts jautājums par valsts piešḳirtā finansējuma palielināšanu ğimenes ārstu praksēm, lai nodrošinātu pacientu veselības aprūpi.

Streiks aktīvi norisinājās no 2017. gada 3. jūnija līdz 18. jūnijam, bet līdz mēneša beigām - palēnināti t. s. go slow veidā. 2018. gadā tika pieṇemts jauns Veselības aprūpes finansēšanas likums [13] un Ministru kabineta noteikumi [15]. Tomēr tie tikai daḷēji risināja giimenes ārstu streikā definēto prasību izpildi.

G̦imenes ārstu streiks izgaismoja juridiskās problēmas, kuras joprojām ne tikai nav atrisinātas, bet nav pat uzsāktas diskusijas par to risināšanu.

Galvenās problēmas ir šādas:

- streika tiesiskais regulējums par tiem nodarbinātības veidiem, kas ir ārpus darba tiesiskajām attiecībām;

- pušu pārstāvniecība sarunu vešanā par darba koplīguma jautājumiem;

- tiesības streikot par jau noslēgta koplīguma nosacījumu neizpildi.

Lai izprastu Satversmē ietverto jēdzienu "strādājošais", jāskata arī nodarbinātības jautājums, jo Latvijā pastāv vairāki nodarbinātības veidi: valsts dienests, kurā pušu saistỉbas pamatā ir administratīvais akts (piemēram, policijas darbiniekiem), ar kuru personu pieñem dienestā un iecel amatā; otrs valsts dienesta saistības veids noteikts ar likumu (piemēram, deputātiem, KNAB darbiniekiem). Savukārt civiltiesiska saistība tiek dibināta ar līgumu (piemēram, darba līgumu, uzṇēmuma līgumu, pārvadājuma līgumu u. c.). Tāpat persona var tikt nodarbināta kā individuālais komersants Komerclikumā [7] noteiktajā kārtībā. Kopumā visas personas, kuras saṇem atlīdzību, ir strādājošie Satversmes 108. panta izpratnē.

G̦imenes ārstu nodarbināšanā iespējami divi veidi. G̦imenes ārsti var praktizēt individuāli gimenes ārsta praksē (kā individuālais komersants) vai slēgt darba līgumu ar ārstniecības iestādi (komercsabiedrību, piemēram, poliklīniku), kura nodrošinās pacientu veselības aprūpi. Pirmajā gadījumā gimenes ārsti atlīdzību saṇem no pacientiem, bet otrajā - no darba devēja jeb ārstniecības iestādes.

Neatkarīgi no nodarbinātỉbas veida, lai îstenotu valsts apmaksātu veselïbas aprūpes pakalpojumu, gimenes ārsta praksei vai komercsabiedrībai katru gadu jāslēdz publisko tiesību līgums ar Nacionālo veselïbas dienestu [9, 4.1. punkts]. Ja ǵimenes ārsts nenoslēdz līgumu ar valsti, viņa pakalpojumus pilnībā apmaksā pacients.

Ģimenes ārstiem paredzēto finansējumu uz gimenes ārstu streika brīdi noteica 2013. gada 17. decembrī piennemtie Ministru kabineta noteikumi Nr. 1529 "Veselïbas aprūpes finansēšanas kārtība” [14], kuri zaudēja spēku 2018. gada 1. janvārī. Tajos noteiktais finansējums arī bija giimenes ārstu streika prasību pamatā. Tādējādi var secināt, 
ka tikai tie gimenes ārsti, kuri noslēguši darba līgumu ar ārstniecības iestādi, ir darba tiesiskajās attiecībās, un viņu domstarpības risināmas Darba strīdu likuma un Streika likuma noteiktajā kārtībā. G̦imenes ārsti nerisināja sarunas par koplīguma noslēgšanu nozarē vai generālvienošanās slēgšanu, bet centās panākt finansējuma palielināšanu veselïbas aprūpei.

Asociācija nav arodbiedrība (darbinieku pārstāvniecība), un tāpēc tā pašreizējā tiesiskā regulējuma ietvaros nevarēja veikt sarunas ar Veselības ministriju vai valdību, kā arī pieteikt streiku. Arodbiedrību likuma 12. pantā noteikts, ka to ir tiesīgas darìt tikai arodbiedrības. Jāpiebilst, ka asociācija nekad nav norādījusi, ka vēlas noslēgt koplīgumu nozarē, tā vietā tika risinātas sarunas par lielāku finansējumu veselības aprūpei. Protams, asociācija kā profesionāla biedru pārstāvniecības institūcija var sarunu ceḷā risināt nozarē identificētās problēmas, kas ir tiešs biedrošanās brīvības apliecinājums demokrātiskā sabiedrībā. Taču ǵimenes ārstiem, lai panāktu normatīvā regulējuma un situācijas izmaiṇas, bija nepieciešams dibināt arodbiedrību, kas tos pārstāvētu sarunās ar Veselības ministriju par koplīguma slēgšanu nozarē. Un tikai tad, ja sarunu iznākums būtu negatìvs, ja puses nevarētu vienoties par koplīguma nosacỉjumiem un interešu sabalansēšanu, arodbiedrība būtu tiesīga pieteikt streiku. Otra iespēja gimenes ārstiem bija pieteikt gājienu vai piketu likumā "Par sapulcēm, gājieniem un piketiem" noteiktajā kārtībā un ar šo protesta formu pievērst sabiedrības uzmanību tām problēmām, kas samilzušas veselības aprūpes nozarē.

Šì situācija skaidri parādīja, ka darba strīdu risināšana Latvijā nav pārdomāta un tā neaptver visus strādājošos: Darba strīdu likumā un Streiku likumā risinājums paredzēts atkarībā no darba strīda pusēm un strīda priekšmeta. Taču ne puses (ne visi ğimenes ārsti ir darbinieki), ne priekšmets (koplīgums) neatbilst Darba strīdu likumam, tāpēc Latvijas G̣imenes ārstu asociācija nebija tiesīga pieteikt streiku. Biedrību un nodibinājumu likums nedod pilnvarojumu biedrībām un nodibinājumiem vest streika sarunas vai to pieteikt. Tādējādi šajā ğimenes ārstu streika gadījumā normatīvais regulējums liedza ǵimenes ārstiem īstenot Satversmē noteiktās tiesības uz streiku.

\section{Secinājumi}

G̦imenes ārstu streiks 2017. gadā parādīja, ka Latvijā tiesiskais regulējums ir nepilnīgs, lai nodrošinātu Satversmē noteiktās tiesības uz streiku visiem strādājošajiem. Pašreiz tiesības streikot ir tikai tai nodarbināto grupai, kam noslēgts darba līgums. Šāds stāvoklis neatbilst ne Konstitūcijā iekḷautajam vienlīdzības principam, ne juridiskajai konstrukcijai par tiesībām uz streiku, jo pieteikt streiku var tikai tajos gadījumos, kad arodbiedrība un darba devēji nevar vienoties par kolektīvajiem interešu strīdiem, līdz ar to tikai arodbiedrībām likums ḷauj piemērot galējo līdzekli - streiku.

Lai risinātu šo nepilnību un tai sabiedrības dal̦ai, kura veic algotu darbu, nodrošinātu konstitūcijā garantētās tiesības, ir jāgroza Darba strīdu likuma 2. pants, kurā definēts darba strīda jēdziens. 
Kitija Bite. Konstitucionālās tiesības uz streiku: gimenes ārstu streika gadijums

Tiek piedāvāts darba strīdu definēt šādi:

Darba strīds ir jebkuras domstarpības, kas izriet no darba tiesiskajām attiecībām vai ir saistītas ar darba tiesiskajām attiecībām, un šīs domstarpības ir starp nodarbināto, nodarbinātajiem (nodarbināto grupu) vai nodarbināto pārstāvjiem un darba devēju, darba devējiem (darba devēju grupu), darba devēju organizāciju vai šādu organizāciju apvienību, vai nozares pārvaldes institūciju.

Nepieciešams grozīt arī Darba strīdu likuma 9. pantu, izsakot to šādā redakcijā:

Kolektīvs tiesību strīds ir tādas domstarpības starp nodarbinātajiem (nodarbināto grupu) vai nodarbināto pārstāvjiem un darba devēju, darba devējiem (darba devēju grupu), darba devēju organizāciju vai šādu organizāciju apvienību, vai nozares pārvaldes institūciju, kuras rodas, slēdzot, grozot, izbeidzot vai pildot koplīgumu, kā arī piemērojot vai tulkojot normatīvo aktu noteikumus, darba koplīgumu vai darba kārtības noteikumus.

Paplašinot darba tiesisko attiecību subjektus no darba tiesiskajām attiecībām uz nodarbinātības tiesiskajām attiecībām, tiktu paplašinātas tiesības streikot tām personām, kuru saistības pamatā ir cits civiltiesisks līgums vai pilnvarojums vai valsts dienesta saistības veids (likums vai administrativvais akts), un dotas tiesības streikot pašnodarbinātām personām. Tādējādi Satversmē minētais termins "strādājošais" tiktu piepildīts ar atbilstošu saturu speciālajos likumos.

Pašlaik nav nepieciešams paplašināt subjektu loku, kas var pieteikt streiku. Tiem jābūt nodarbināto pilnvarotiem pārstāvjiem (arodbiedrībai).

Tomēr nepieciešams uzsākt diskusiju, vai nevajadzētu paplašināt tiesības uz streiku gadījumos, kad koplīgums ir noslēgts (aktīvā darbībā), bet darba devējs vienpusēji to nepilda. Starptautiskajos normatīvajos aktos tiesības uz streiku ir cieši saistìtas ar koplīgumu, bet nav strikti noteikts, ka streiks būtu piemērojams tikai par kolektīviem interešu strīdiem. Arī kolektīvie tiesību strīdi varētu būt risināmi ar streika palīdzību.

Kopumā var secināt, ka Latvijā formāli ir nodrošinātas tiesības uz streiku, bet, lai tās reāli varētu īstenot, nepieciešams grozìt normatīvos aktus un uzsākt diskusiju par tiesību uz streiku paplašināšanu attiecībā uz kolektīviem tiesību strīdiem. Svarīgi ir nodrošināt konstitūcijā noteiktās tiesības uz biedrošanās brīvību un tiesības strādājošajiem streikot, bet tajā pašā laikā streiks nav līdzeklis, ko izmantot visās situācijās, kad pušu intereses nesakrìt.

\section{Constitutional Rights on Strike - General Practitioner`s Strike Case}

\section{Abstract}

International legal provisions provide for human rights and freedoms, and the freedom of expression and the right to work are part of these. Considering that during any employment relationship disputes can arise between the involved parties, international 
legal provisions for that provide strike as the final means to be utilised for the settlement of a dispute. Paragraph 108 of the Satversme (the Constitution of Latvia) provides that in Latvia, employed people have the right to strike. Systematically, the provisions of the Constitution are being regulated by the Labour Dispute Law and the Strike Law. It might seem that in Latvia, any employed person has been entitled to the right to strike as provided by the Satversme. However, the strike of general practitioners in summer 2017 highlighted a problem of executing strikes. Firstly, at the time being, the right to strike can be only associated with one form of employment, i.e., employment relationship. As only a part of general practitioners is employed on the basis of an employment agreement, the strike regulatory framework that is in force in Latvia can be used only by a part of general practitioners employed under an employment agreement in order to protect their collective interests. Secondly, the Labour Dispute Law provides for that a strike as the final means can be utilised exclusively for the protection of collective interests (within the framework of concluding a collective agreement), but not within the framework of a contract governed by the public law. The strike by general practitioners showed that Latvia has complied only partially with international legal provisions because a strike can only be utilised by people employed under employment agreements and only in disagreements regarding a collective agreement. In order to resolve this problem and so that any employed person is entitled to the right to strike in the future, it is necessary to amend the Labour Dispute Law by expanding the range of labour dispute subjects.

The aim of the article is to analyse both international regulatory framework and that in Latvia for the right of employed people to strike and to recommend necessary amendments to laws to solve the detected problems.

Materials used for the compilation of the article: international legal provisions and Latvian legal acts, publications and literature. Methods used in this article: descriptive, analysis, synthesis, dogmatic, induction and deduction, graphic as well as legal interpretation methods - grammatical, systemic, historical and teleological.

Keywords: labour dispute, strike, employment, strike of general practitioners, employment agreement, collective agreement.

\section{Avoti un literatūra}

\section{Tiesību akti}

1. Arodbiedrību likums: Latvijas Republikas likums: pieṇemts 06.03.2014. un stājās spēkā 01.11. 2014. Latvijas Vèstnesis. 60, 25.03.2014.

2. Biedrību un nodibinājumu likums: Latvijas Republikas likums: pieṇemts 30.10.2003. un stājās spēkā 01.04. 2004. Latvijas Vēstnesis. 161, 14.11.2003.

3. Darba likums: Latvijas Republikas likums: pieṇemts 20.06.2001. un stājās spēkā 01.06.2002. Latvijas Vēstnesis. 105, 06.07.2001.

4. Darba strīdu likums: Latvijas Republikas likums: pieṇemts 26.09.2002. un stājās spēkā 01.01.2003. Latvijas Vētnesis. 149, 16.10.2002. 
Kitija Bite. Konstitucionālās tiesības uz streiku:

gimenes ārstu streika gadijums

5. Eiropas Sociālā harta: starptautisks dokuments. Latvijas Vēstnesis. 38(2803), 11.03.2003.

6. International Covenant on Economic, Social and Cultural Rights: ANO starptautiska konvencija. OHCHR. Iegūts no: https://www.ohchr.org/en/professionalinterest/pages/cescr.aspx [sk. 13.05.2019.].

7. Komerclikums: Latvijas Republikas likums: pieṇemts 13.04.2000. un stājās spēkā 01.01.2002. Latvijas Vēstnesis. 158/160, 04.05.2000.

8. Latvijas Republikas Satversme: Latvijas valsts likums: pieṇemta 15.02.1922. un stājās spēkā 07.11. 1922. Latvijas Vēstnesis. 43, 01.07.1993.

9. Nacionālā veselības dienesta nolikums: Latvijas Republikas Ministru kabineta noteikumi Nr. 850: pieñemts 01.11.2011. Latvijas Vēstnesis. 178, 10.11.2011.

10. Par sapulcēm, gājieniem un piketiem: Latvijas Republikas likums: pieṇemts 16.01.1997. un stājās spēkā 13.02.1997. Latvijas Vēstnesis. 31/32, 30.01.1997.

11. Publisku izklaides un svētku pasākumu drošības likums: Latvijas Republikas likums: pieṇemts 16.06.2005. un stājās spēkā 20.07.2005. Latvijas Vēstnesis. 104, 06.07.2005.

12. Streiku likums: Latvijas Republikas likums: pieṇemts 23.04.1998. un stājās spēkā 26.05.1998. Latvijas Vēstnesis. 130/131, 12.05.1998.

13. Veselïbas aprūpes finansēšanas likums: Latvijas Republikas likums. Latvijas Vēstnesis. 130/131, 12.05.1998.

14. Veselības aprūpes organizēšanas un finansēšanas kārtība: Latvijas Republikas Ministru kabineta noteikumi Nr. 1529: pieṇemti17.12.2013. un zaudēja spēku 01.09.2018. Latvijas Vēstnesis. 253, 30.12.2013.

15. Veselības aprūpes pakalpojumu organizēšanas un samaksas kārtība: Latvijas Republikas Ministru kabineta noteikumi Nr. 555: pieñemta 28.08.2018. Latvijas Vēstnesis. 176, 05.09.2018.

\section{Tiesu prakse}

16. Satversmes tiesas 2007. gada 16. maija spriedums lietā Nr. 2006-42-01 "Par Streiku likuma 24. panta trešās daḷas atbilstību Latvijas Republikas Satversmes 108. pantam”. Latvijas Vēstnesis. 81, 22.05.2007.

\section{Literatūra}

17. Katlaps, A. Streiku kustība Latvijā. Providus domnīca. 18.12.2002. Iegūts no: http://providus.lv/ article/streiku-kustiba-latvija [sk. 23.04.2019.].

18. Mickeviča, N., Rācenājs, K. 2015. Arodbiedrību likums ar komentāriem. Rīga: Latvijas Brīvo arodbiedrību savienība.

19. Olsena, S. Pirmais Latvijas ğimenes ārstu streiks: faktiski, tiesiski un prettiesiski. Jurista Vārds. 41, 03.10.2017., 10.-18. lpp.

20. Spūle, I., Tiḷ̦a, A. 2007. Biedrošanās brīvība. Rīga: Latvijas Republikas Tiesībsargs.

21. Streiks. LSM.LV Iegūts no: https://www.lsm.lv/temas/streiks/ [sk. 12.02.2019.]. 